УДК 78.071.1 (477) + 78.082: 788

\title{
ДЕНИСЕНКО Я.О.
}

https://orcid.org/0000-0002-0565-4148

Національний Президентський оркестр (Київ, Україна);

denisenkojarina@gmail.com

\section{«ТЕХНЕМИ》 ДЛЯ ДУХОВИХ ІНСТРУМЕНТІВ ГЕННАДІЯ ЛЯШЕНКА В КОНТЕКСТІ ЖАНРОВО-СТИЛЬОВИХ ЗАСАД СУЧАСНОЇ УКРАЇНСЬКОЇ ІНСТРУМЕНТАЛЬНӦ̈ МУЗИКИ}

Становлення європейського інструментального репертуару - як сольного, так і ансамблевого - відбувалося за умов жанрово-стильового синтезу. Ця ж тенденція визначає i сучасний український репертуар для гобоя та ансамблів за участю гобоя. У даному контексті проаналізовано два цикли «Технем» Г. Ляшенка (з п'яти циклів інструментальних концертних п’єс для різних складів) - «Технема № 1» для духового квінтету і «Технема № 4», яка $\epsilon$ по суті подвійним концертом для гобоя та фагота. Простежені ознаки стильового синтезу на тематичному рівні, визначено розвиток форми і вказано на спорідненість із романтичною та бароковою традиціями. бароко.

Ключові слова: гобой, фагот, концертштюк, стиль, інструментальні концерти,

Постановка проблеми. Окремою формою існування твору мистецтва є його художньо-естетична інтонаційність. Європейське коріння інтонаційної виражальності породжує поняття «інтонаційної атмосфери» (М. Чехов), «темброінтонаційності» твору; окреслюється тенденція до персоніфікації тембру, використання його як самостійного інтелектуально-експресивного знаку - виразного засобу інструментальної музики, що бере початок в епоху бароко, коли активно розвивається світська і духовна музика. Експресивність барокового стилю виражається в яскравій колористиці та пишній декоративності; відчуття різнотембрового простору, створюване використанням поліфонічних імітаційних форм, впливало на специфічно театральне сприйняття музики. Українські композитори засвоїли цю техніку та перевтілювали їі на своєму національному грунті ${ }^{1}$.

Не менш виразні, традиції романтичного напрямку в українських симфонічних творах пов'язані з процесом «олюднення інструменталізму» (Б. Асаф'єв), граничного розширення можливостей духової групи, інструментальне звучання якої набуває характеру вокального інтонування. Порівняння духових із чотирма типами людських голосів (гобой - жіноче сопрано чи альт, кларнет - сопрано, альт чи тенор,

\footnotetext{
${ }^{1}$ Часто ця музика виконувалася ансамблем інструментів, у якому брали участь і гобої. Відомі транскрипції хорових творів цього часу, зроблені сучасними українськими композиторами: М. Денисенко, Ю. Іщенком, Л. Колодубом, Л. Юріною, ряд транскрипцій здійснено гобоїстом М. Кононовим.
} 
валторна - тенор чи високий бас, фагот - бас чи низький бас), якнайкраще виражало народнопісенну основу музики перших українських симфоній (О. Вандерброк) ${ }^{1}$.

На українському грунті популярною стає концертність салонного типу: виконання «капелами», жанр дуетного співу та камерні форми інструментального музикування розвиваються в цей час дуже інтенсивно, причому, як у Західній, так і у Східній Україні. Жанри західноєвропейського мистецтва, відомі як концертштюки - одночастинні концертні твори з одним, двома, трьома сольними партіями, набувають популярності в домашньому (салонному) музикуванні у XIX столітті та відновлюють своє значення в кінці XX-го, з розширенням можливостей перформансних форм.

В українській музиці гобой як інструмент сольного та ансамблевого виконавства практично заявлений у творчості кожного українського композитора: у XX столітті створено велику кількість п'єс, ансамблів, творів дрібних і великих форм за участю гобоя. Після 20-х років XX століття, у зв'язку з широким використанням гобоя в європейській інструментальній музиці та з поширенням національних виконавських шкіл, виникає цікавість українських композиторів до камерних інструментальних складів за участю гобоя (популярними стають жанри тріо, квартету, змішаних складів та духові квінтети) ${ }^{2}$. Персоналізований тембр гобоя в українській музиці має широке поле застосування як у фольклорно-декоративному напрямку, так і в академічних камерних творах.

Гобой є незмінним учасником духових ансамблів - тріо, квартетів, квінтетів, що стали особливо популярними в українській музиці другої половини ХХ ст. (твори Я. Верещагіна, Г. Гаврилець, Л. Грабовського, М. Денисенко, Л. Колодуба, Г. Ляшенка, В. Рунчака, Є. Станковича та ін.).

Метою статті $\epsilon$ привернення уваги до оригінального ансамблевого жанру за участю гобоя - «Технеми», започаткованого Геннадієм Ляшенком, як новаційного типу камерної музики. Тут стикаємося 3 широким розумінням жанрового синтезу, оскільки існує і пряма вказівка на жанр: квінтет (№ 1), подвійний концерт (№ 4) i т. ін. Тобто, «технема», як тип музикування охоплює різні склади, різні жанри та види концертності, з властивими їм контрастністю образів та віртуозністю. Викликаний до життя потребами виконавців-інструменталістів у сучасному репертуарі та у зв'язку з пожвавленням фестивального процесу в Україні, цей жанр зайняв певне місце, як у інструментальній творчості Геннадія Ляшенка, так і в українській музиці в цілому. Так, на замовлення виконавськими колективами (духові квінтети «Престиж», «Глорія», фестивальний Квінтет Національної спілки композиторів України) та музичними менеджерами (В. Балей та ін.), київськими композиторами у 1990-ті роки написано цілий ряд Квінтетів для духових інструментів. Таким чином, європейська традиція квінтетного музикування в українській музиці вступила в нову фазу розвитку ${ }^{3}$.

${ }^{1}$ Як відомо, вже на ранньому етапі українського симфонізму Е. Ванжура робить спробу відтворення духовими інструментами сольного, діалогічного та хорового співу.

${ }^{2}$ Ставлення до гобоя як до носія певного образу, як до інструменту, за тембром близького мелодичності людського голосу, викликало до життя твори М. Вериківського, Р. Глієра (балет «Червоний мак»), Б. Лятошинського (симфонії, Квартет для духових), Л. Ревуцького (Друга симфонія) та ін., в яких гобой має сольну функцію.

3 Для квінтету духових, окрім Г. Ляшенка, на рубежі XX-XXI століть пишуть С. Бедусенко, М. Безуглов, В. Бібік, Г. Гаврилець, В. Годзяцький, В. Гомоляка, В. Губаренко, М. Денисенко, В. Журавицький, С. Зажитько, Ю. Іщенко, В. Кафарова, О. Красотов, С.Луньов, М. Скорик, С. Станкович, М. Шух, О. Щетинський, Л. Юріна, О. Яворик та ін. 
Викладення основного матеріалу. В ансамблевій музиці для духових за участю гобоя, створених українським композиторами, критики відзначають успішні спроби поєднання модерного, фольклорного та популярного музичного мистецтва, що визначає як жанрово-стильові зміни, так і проблематику виконавства в ансамблевій сфері. Примітно, що композитори, які звертаються до духових інструментів, підсвідомо орієнтуються на специфічну «натуральність» $\mathrm{i}$ автентичну природу цих інструментів, на їх темброву близькість до мовної інтонації, на емоційність та багатий спектр виражальних можливостей. Синтез традиційного розуміння ансамблевої функції духових інструментів і нових можливостей, які дає кожний тембр в ансамблі, стають широким полем для досліджень в інтерпретаційній царині духового ансамблевого виконавства.

У 1960-ті роки в зв’язку з новаторською творчістю польського авангарду В. Лютославського, К. Пендерецького та композиторів, послідовників пуантилізму та серіалізму, і надалі, окрім інтенсивного розвитку жанрів ансамблевої камерної музики за участю гобою, відбувається ренесанс концертних жанрів для гобоя. Це спостерігаємо як у польській, чеській, німецькій, російській музиці, так, певною мірою, це торкається і української духової спадщини ${ }^{1}$. Фестивальний процес пожвавлює тенденції інструменталізму схильністю до театралізації, сценічного удосконалення ідеї, використання фольклору, імпровізації - тобто до явної чи прихованої програмності ${ }^{2}$.

У Геннадія Ляшенка, музичній мові якого притаманна жанрова багатоманітність, звернення до технологій сучасної музики (алеаторики, сонорики, полігармониї, політональності), одночасно присутній зв’язок із традиціями класичної форми, драматургії. Зокрема, у його камерно-інструментальній музиці зустрічаємо переосмислення архітектоніки класичних форм, схильність до наскрізного розвитку. Як вказують дослідники його творчості, «художньому мисленню композитора притаманна філософська глибина, багатовимірність сприйняття <...> водночас, потяг до програмності, епіко-драматичний тип творів; у нього відзначаються тематичні та смислові арки між різними творами» $[1,52]$.

Музика для духових Геннадія Ляшенка, як і його вокальні твори, «позначена тонким відчуттям просторового начала, вишуканістю і барвистістю гармонії та мелодики» $[1,52]$. Серед його творів для духових значне місце займають «Технеми» № 1 для квінтету духових та № 4 - для гобою та фагота з камерним оркестром. Написані в різний час (1994 та 2016 рр.), ці композиції своєрідно відтворюють еволюцію жанру в напрямку посилення його концертності.

Як зазначено раніше, сам жанр «Технем» є однією з оригінальних форм в українській камерній музиці, ідея якої належить саме Г. Ляшенку: спорідненість віртуозного концертування з поемою симфонізованого типу, «музика станів», «повітряність» i колористична картинність, каденційність i, водночас, присутність як основи безперервного животворного руху - perpetuum mobile, дозволяють говорити про цей жанр як про універсальний мисленнєво-емоційний та динамічний тип висловлювання.

«Технема № 1» для квінтету дерев’яних духових продовжує лінію пошуків відтінків темброво-колористичної гами духових інструментів; тут діє принцип тем-

${ }^{1}$ Концерти Ю. Бабенка, В. Балея, В. Гомоляки, М. Дремлюги, О. Зноско-Боровського, Ю. Іщенка, В. Камінського, Л. Колодуба, С. Турнеєва; Concerti grossi 3. Алмаші, Г. Таранова, квартети Б. Буєвського, Д. Клебанова, С. Крутикова, Ю. Фіали, Г. Цицалюка, І. Шамо та ін.

2 Українськими композиторами написано чимало програмних творів, що свідчить саме про популярність трактування гобоя як своєрідного театрально-сценічного персонажу. 
брового «перехрещення», який впливає як на контекстово-драматургічну сферу, так i на виражальну. Композитор використовує експериментальні виражальні засоби, метроритмічні (ізоритмічні) модуси, притаманні старовинній поліфонії, модальні лади, при цьому зберігаючи «високу ноту» емоційного та духовного напруження сучасності, індивідуальну манеру письма. «Автор користується тут лише декількома типами прийомів тембрового оформлення тематичного матеріалу, які підкреслюють характерний стан очікування події, непевності та сумнівів» $[1,54]$. Певну роль у цьому відведено гобою.

Темброелементи звучання складаються у цілісне за колоритом образне «плетиво», що створює ілюзію об'ємного простору, в якому ефект відлуння є драматургічним засобом, формою імітації темброгармоній. Лінеарний розвиток відбувається завдяки мікро-мотивним, ладовим та ритмічним змінам у темброгармоніях. Такий «ланцюговий» зв'язок, притаманний драматургії цього твору, так званий «континуально-контрастний» принцип розвитку, висуває певні вимоги до виконавців: зокрема, партія гобоя тут - це той остов, навколо якого будуються сонорно-алеаторичні комплекси, що забезпечують «еволюційний “рух форми” $[1,54]$.

Саме у цьому творі тематичний та фактурний мінімалізм дозволяє спостерігати процес народження нових сенсів, вміщених у музичну тканину, що постійно оновлюється. Критики відзначають здатність композитора у своїй музиці торкатися сокровенних сенсів, що викликає у душі слухача дивовижні резонанси: «Геннадій Ляшенко постає яскраво оригінальним й органічно вписаним у світовий культурний контекст, національно визначеним і орієнтованим на загальнолюдські цінності» [3, 5].

Використання нових ідей у формуванні репертуару другої половини XX столыття великою мірою було залежним від появи ряду новаційних посібників, етюдів та керівництв ${ }^{1}$. У 1980-90-х роках українськими композиторами було написано ряд творів традиційних жанрів (сонати, цикли п’єс, варіації). Водночас відбувався процес «автентизації» інструменту i, в зв'язку з цим, звернення до барокових канонів. Трактування тембру гобою як стилістично узагальнюючого, пов'язаного з добою Бароко тембрового знаку (що, наприклад, знаходимо у творах І. Стравінського: «Пульчинелла», «Історія солдата», «Весна священна»; в ансамблях Ф. Караєва, у композиції «Візерунки» Л. Грабовського та ін. ), заклало початки так званих синтезованих жанрів, зразками яких і виступають духові «Технеми» Г. Ляшенка.

«Технема» № 4 (2016) - твір концертно-симфонічного плану, написаний для солістів гобою та фагота з парним складом симфонічного оркестру. Так як і подвійні концерти, цей жанровий різновид концертного типу має значний масштаб. Поперемінна експозиція головних образів спонукає до трансформації традиційної тричастинної форми у сенсі нанизування контрастно-складових епізодів, залучення засобів наскрізного розвитку, поліфонічних варіаційних прийомів, чергування експозиційних та розробкових фрагментів, використання колористики та ін.

3 самого початку експозиція тематичних ідей відбувається на тлі педальних акордів pp у струнних sul ponticello. Три акордові групи, як часто буває у Г. Ляшенка, утворюють вступний розділ. Діалогічність наступних епізодів виявляється навіть у парності дублюючих голосів. Мікст тембрів - альти-віолончелі - відіграють роль

${ }^{1}$ Таких, наприклад, як Bruno Bartolozzi\ Lawrence Singer, Metodo per Oboe (Suvini Zerboni); Bruno Bartolozzi New sounds for woodwind (Schott); Reinghard Luttman, 21 Etuden uber eine zwolftonreihe (Leduc), Peter Veale, Claus Steffen Mankopf "The technique of oboe playing" та ін.

74 ISSN 2522-4190. Науковий вісник Національної музичної академії України імені П. І. Чайковського. 2018. Вип. 122 
струнної «опори», що як, наприклад, в епізоді від т. 40, де вступає друга тема (тема хоралу), доповнюються мікстом оркестрових тембрів кларнету та фаготу.

Колористичною цезурою у розгортанні основного матеріалу стає каденція вібрафону (тт. 45-58), який є зв'язуючим тембром (у діалозі гобою та фагота, між кульмінаційними підйомами та поверненням до висхідної динаміки (як, наприклад, у епізоді 60-70 тт., де діалог сольних голосів звучить на тлі хоралу). Це є одним 3 прикладів своєрідного жанрового синтезу. Оригінальна тричастинність експозиції (головна тема - тт. 11-29, далі тт. 30-70 - умовна розробка декількох поперемінно виникаючих інтонацій, що мають функцію сполучних, призводить до тт. 76-79невеликої кульмінаційної зони, яка зв'язує попередній епізод із репризою головної теми (у експозиції).

Якщо вважати форму «Технему № 4» близькою до класичної сонатної, то розробка настає в епізоді Allegro moderato (від т. 90). Репліки з попередніх тем активізуються у синхронному русі струнних та солістів. Настає епізод сонорних звучань (тт. 110-138), сенс якого, вірогідно, у самозаглибленні та пошуках гармонії через пізнання внутрішнього світу тощо. Цей епізод є драматургічною (тихою) кульмінацією «Технеми № 4». Таємниче колоритне звучання мультиакордів у солістів (ефект відлуння) у супроводі мідної групи на тлі тихої педалі струнних несподівано змінюється дрібним крещендуючим рухом усього оркестру.

Несподіваний сплеск миттєво стишується; нова кульмінаційна зона (від т. 16о) так само моментальна, вона призводить до появи теми-візерунку, що звучить у супроводі туби. Цю тему можна порівняти з експозиційною, де доповнюючим тембром виступає вібрафон. Колористично-орнаментальна мелізматика у гобою доповнюється мелодичними візерунками фаготу: в'юнкі орнаменти то наближаються у «перегрі», то віддаляються. Фольклорно-бароковий характер цього епізоду, знову ж таки, вказує на жанровий синтез, через який у кульмінаційній зоні твору об'єднуються різні ментально-інтонаційні якості.

Декілька фаз заспокоєння і повернення до напруженого руху «ліплять» гетерофонно-поліфонічну форму, що послідовно розгортається у горизонталі. Інтонації у солістів походять 3 риторичних формул (як, наприклад, у т. 275 - контрапункт фагота до теми гобою), підкреслюють барокову вишуканість фактури.

Відносно вільний за формою (тричастинна або сонатноподібна форма з яскраво вираженою зміною контрастних епізодів, що властиво романтичній традиціі), одночастинний розгорнутий концертний твір, в якому віртуозні епізоди займають провідне місце, наближений до жанру концертштюка, в якому поліфонічна розробковість сольного матеріалу вказує на барокові жанрові зв'язки.

Висновки. Отже, в підсумку короткого аналізу двох концертних п’єс з циклу «Технеми» можна зазначити певну подібність обох композицій, попри значну ї відмінність. «Музика Г. Ляшенка, - на думку М. Ржевської, - має яскраве “звукове обличчя”, водночас вона - своєрідний конгломерат інтонаційних образів, властивих українській музичній культурі» [2]. Саме національна визначеність інтонаційного словника «Технем», не буквальна, не ілюстративна, а сутнісно-поміркована, енергетично природна, об'єднує різні за концепцією і жанром концертні твори Г. Ляшенка. Концертштюкова віртуозність у «Технемі № 4» та панорамна медитативність «Технеми № 1» пов’язуються саме мовностильовими параметрами. Така індивідуальна оригінальність музичної мови (застосування прийомів поліфонічної варіаційності, деталізація ладово-інтонаційних рядів, примхлива колористика тембрів, тощо) та їі інтеграція в загальноєвропейський жанровий контекст i $\epsilon$, як свідчить Т. Сачева, головними показниками композиторського стилю Г. Ляшенка [4]. 
Таким чином, за принципом багатожанровості та стильового плюралізму (Б. Сюта) формуються не тільки потреби виконавців у сучасному репертуарі, але й композиторські ідеї. Традиція творчої взаємодії «виконавець-композитор-виконавець» продовжує зберігати свою актуальність, а в деяких випадках вона стає формою інтерпретаційної творчості, співавторства. Так, «Технема № 1» для духових Г. Ляшенка, яка з'явилася під впливом творчого спілкування з музикантами духового квінтету «Престиж» Дніпропетровської філармонії, та «Технема № 4», ідея якої народилася в процесі нашого творчого спілкування 3 автором, стали визначними віхами доробку композитора і його блискучим внеском в скарбницю духового виконавського мистецтва.

\section{СПИСОК ВИКОРИСТАНИХ ЛІТЕРАТУРИ І ДЖЕРЕЛ}

1. Денисенко М. Традиції європейської культури у творах для духових інструментів Геннадія Ляшенка // Науковий вісник Національної музичної академії України імені П.І. Чайковського. Вип. 83 : Проблеми методики та виконавства на духових інструментах (вокальне та інструментально-духове мистецтво). Київ, 2009. С. 51-62.

2. Ржевська М. Музичний світ Геннадія Ляшенка. URL: http://slovoprosvity.org/2008/01/30/145-old/ (дата звернення: 16.02.2018).

3. Ржевська М. Риси симфонічної творчості Геннадія Ляшенка // Мистецтвознавчі записки. Київ : ДАККіМ, 2013. Вип. 24. С. 3-8.

4. Сачева T. Сторінками музики Геннадія Ляшенка. URL: http://www.umoloda.kiev.ua/number/1315/164/46426/ (дата звернення: 06.02.2018).

\section{REFERENCES:}

1. Denysenko, M. (2009), "Traditions of European culture in works by Hennady Liashenko for wind instruments", Naukovyj Visnyk Nacionaljnoji muzychnoji akademiji Ukrajiny imeni P.I.Chajkovsjkogho [Scientific Bulletin of the National music academy of Ukraine named after P. I. Tchaykovsky], vol. 83, Kyiv, p. 51-62 [in Ukrainian].

2. Rzhevska, M. (2008), "Musical world of Hennady Liashenko", available at: http://slovoprosvity.org/2008/01/30/145-old/ (accessed: 16 feb 2018) [in Ukrainian].

3. Rzhevska, M. (2013), "Features of symphonic art by Hennady Liashenko", Mystectvoznavchi zapysky [Art-Studies Notes], vol. 24, p. 3-8. [in Ukrainian].

4. Sacheva, T. (2008), Pages of music by Hennady Liashenko, available at: http://www.umoloda.kiev.ua/number/1315/164/46426/ (accessed 16 February 2018) [in Ukrainian].

Стаття надійила до редакиії 02.03.2018 p.

\section{YARYNA DENYSENKO}

https://orcid.org/0000-0002-0565-4148

National President's orchestra. Kyiv, Ukraine

denisenkojarina@gmail.com

\section{Hennady Liashenko's «Technems» for winds incontemporary context of Ukrainian instrumental music}

Relevance of the study. The main direct of the European instrumental music development is a genre and stylish synthesis. A lot of contemporary oboe solo and en- 
semble with oboe works by Ukrainian composers are signed by those charakteristik. For example, the cycle of «Technems» by $\mathrm{H}$. Liashenko from the five instrumental concert pieces, - hich have inside two original compositions with oboe, - take an important place in the composer's creation; this pieces are known as the wide examples of contemporary concert repertuar for ensembles. They present a new kind of chamber music which was beginning with the Liashenko's «Technems», and it's not researching enough till now. Main objective of the study is to pay attention to this new and original genre for ensemble with oboe - «Technem № 1 » for wind quintet and «Technem № 4» for oboe and fagot as soloists with the baroque symphony orchestra. Methodology The provident in this study is the comparative analyses' method. How the study was done. The «Technem № 1» for wind quintet we're noting as the stylish unite. It's based on individual composer's meaning about the melodically uniting of the themes and about it's rules. The important direct of studying in Liashenko's works is his meaning about "growth in form»: the whole is growth from one element. Thanks to using those principal means in his compositions, work's structure look like the one qualities unit, while inside ones we can find a different types of intonations and of stylish elements. Results and conclusions. The sphere of wind concerts is continue by «Technem № 4", which seems as a double concert for oboe and fagot. It is the next step in the composer's process, when the main characters of stylish synthesis are seeing on the level of intonation, form and shows the kind of nearby connections between romantic and baroque. Practical significance. The well-known connective tradition "performer - author - performer» is actually till today, and sometimes we can trade it as the corporative form of interpretation as creation. baroque.

Keywords: oboe, fagot, wind quintet, double concert, style, instrumental genres,

\section{ДЕНИСЕНКО Я.А.}

https://orcid.org/0000-0002-0565-4148

Национальный Президентский оркестр (Киев, Украина);

denisenkojarina@gmail.com

\section{«Технемы» для духовых инструментов Геннадия Ляшенко в контексте жанрово-стилевых особенностей современной украинской инструментальной музыки.}

Актуальность исследования. Основой развития европейского инструментального репертуара является жанрово-стилевой синтез. Этим же признаком отмечены многие из сольных и ансамблевых сочинений современных украинских композиторов, в частности, с участием гобоя. Цикл «Технем» Г. Ляшеенко - из пяти инструментальных концертных пьес (концертштюков), в т.ч. две композиции с участием гобоя, - занимают важное место в творчестве композитора и являются яркими образцами современного ансамблевого концертного репертуара. Этот новационный тип камерной музыки, начало которому положил Геннадий Ляшенко, остается до сих пор недостаточно исследованным. Целью статьи является привлечение внимания к оригинальному ансамблевому жанру с участием гобоя - «Технемы № 1» для духового квинтета и «Технемы № 4» для гобоя и фагота 
с парным составом симфонического оркестра. Методы исследования. Ведущим в работе является метод сравнительного анализа.

Выводы. В «Технеме № 1» для духового квинтета отмечаем стилевую целостность, основанную на индивидуальном подходе композитора к вопросам интонационного единства тематизма, на его понимании «проращивания формы» из единого материала, что обеспечивает ее структурную плотность, при многослойности составляющих компонентов. «Технема № 4» является, по сути, образцом редкой разновидности жанра «двойного концерта». Признаки стилевого синтеза прослеживаются здесь на жанрово-тематическом уровне, определяя развитие формы и указывая на родство с романтической и барочной традициями. Практическое значение. Традиция творческого взаимодействия «исполнитель-композитор-исполнитель» сохраняет свою актуальность, а в некоторых случаях она становится формой интерпретационного сотворчества.

Ключевые слова: гобой, фагот, духовой квинтет, двойной концерт, стиль, инструментальные жанры, барокко. 